\title{
Educational Technology and Resource- Based Learning as Applied to Nursing Education
}

\author{
I.M. Miles, \\ Co-ordinator, Nursing Education \\ Technology, Cape Province
}

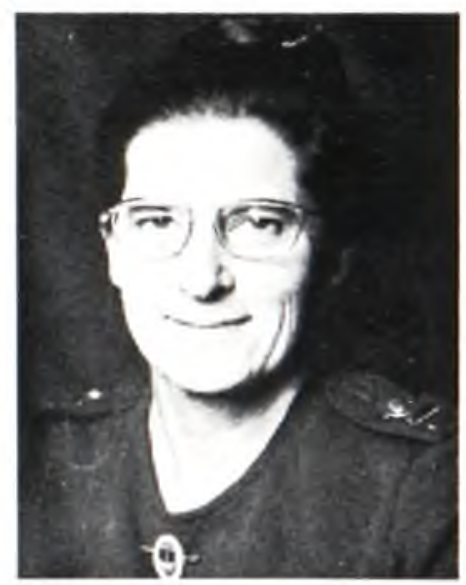

\section{OPSOMMING}

Hierdie artikel bespreek die agtergrond van opvoedkundige tegnologie en die trefkrag daarvan op alle fasette van die onderwys. Daar word definisies gegee van "opvoedkundige tegnologie" in die ruimste sin van die woord en ook van opvoedkundige tegnoloë. Bloom se taksonomie van opvoedkundige doelstellings op die kognitiewe en affektiewe terreine word met betrekking tot die ontwikkeling van 'n sistematiese benadering tot die leersituasie bespreek. Die elemente van 'n sistematiese benadering tot die opstel van leerplanne word ook vermeld. Die konsep van die totale onderwyser word uitgewerk, asook onderwysergesentreerde, leerdergesentreerde en vennootskapsmetodes in die leersituasie. Die kenmerke van opleiding teenoor opvoeding en leerstelsels wat op onderwys gebaseer is teenoor die wat op hulpbronne gebaseer is, word geskets. Hulpbronne wat op leer gebaseer is sowel as die implementering van hulpbronne gegrond op die leerervaringskeël, word bespreek. Die beginsels, kenmerke en voorwaardes vir die beheer van hulpbronnesentra word behandel, en ten slotte word daar melding gemaak van enkele toepassings op verpleegonderwys.

$\mathbf{H}$ istorically there have been four major revolutions in education. The first took place when education of the young shifted from parent to teachers and schools eg. the Rabbinical schools and Muslim schools in which instructions were previously tribal and religious, and based on oral communication and memory work.

Secondly, the written word superseded oral instruction in that it became an aid to memory, and a source of stored information as knowledge expanded.

Thirdly, the invention of printing and the subsequent increase and availability of printed material made learning accessible to more people.

After an interval of five centuries the fourth revolution in education occurred as a result of the application of modern communications technology, electronic devices and the systems approach to education. (Carnegie Commission Report on Higher Education, 1972.)

Furthermore, factors putting pressure on the present educational approach are the population explosion, the knowledge explosion, new developments and applications in the psychology of learning and the technological device explosion. 
The possibility for the improvement of teaching and learning experiences by means of educational hardware and software is immense, but in order to make effective use of them educationists are finding it necessary to re-evaluate and redesign curricula.

The impact of applications of educational technology has affected all facets of education:

Educational equipment is vastly improved in terms of quality, quantity and ease of use: the traditional school environment is changing in that through improved information retrieval systems and self-instruction learning approaches the ordinary classroom restraints such as rigid timetables begin to fall away; traditional attitudes to education are changing in that young people are increasingly in contact with a larger world because of mass communications, mass transport and highly developed consumerism. They realise the accessibility of a vast store of knowledge and the means to get it. This has demoted the traditional educational institution from being the only major official source of knowledge. Students are no longer awed by the "learned authority" nor by present developments in machine technology.

Instructional methods of teaching and learning are affected in that the computer age has brought the analytical systems approach. This has resulted in an attempt to refine curricula and use a more logical and co-ordinated approach to curriculum development.

\section{EDUCATIONAL TECHNOLOGY}

All this has led to the broad concept of Educational Technology. This term derives from "techne" = art, craft; and "logia" = systematic study. Accordingly it has to do with the art of systematically arranging, observing or doing things, or using any logical technique, device or process. When applied to education the average interpretation is usually confined to the use of man-made devices, but the true concept of educational technology is much broader than that.

According to the Council for Educational Technology for the United Kingdom: "Educational Technology" may be explained as a planned systematic (scientific) approach to the learning situation. It takes into account the organisation and implementation of modem learning systems (the "systems" approach is much used in techniques evolved from the psychology of learning as applied in the industrial world); and takes advantage of the facilities offered by modern communication methods, visual aids, classroom organisation and teaching methods (modern communication systems and media have greatly influenced the learning process); the role of the teacher changes from that of traditional type instructor to that of manager of the total learning situation (planning. organising, executing and controlling in a systematic welldeveloped way), while the role of the student changes from that of passive recipient of information (with often a complete lack of transfer of knowledge) to that of an active participant in the learning process, passing through activities and learning experiences designed to help him meet specific. meaningful and relevant learning objectives. The accent is on "learning by doing". Finally the learning process is measured against specific criteria (criterion-referenced instruc- tion) to see if the learner has reached the desired learning outcome and competencies. (Council for Educational Technology: Information Leaflet 1.)

Educational technology therefore aims to put the principles of psychology, philosophy, and methods of learning into a systematic practical application adapted to the changing learning needs of modern times. It aims also to make for better quality teaching, to enhance educational power and to prevent the type of educational malpractice which fails to meet the students' learning needs because it is inadequate in design, irrelevant in content, or under- or over-supplied in content.

Educational technology helps teachers make the fullest and most effective use of all types of study materials and media available to them in either a college situation or from other services. It helps them develop their individual and corporate production of evaluated study materials in accordance with students ${ }^{*}$ learning needs and existing facilities. It assists them in the development of procedures for the organisation and management of all types of learning resources and last but not least, helps them to put the learning needs and personal development of the student, central to the learning situation.

"An educational technologist is a person who seeks to apply this body of knowledge to the problems of curriculum planning. selection of strategies and media as well as to student assessment and evaluation. It goes further and focuses on the teacher and his teaching as well as the student and his learning." (Bob McCormick: Institute of Educational Technology: Open University).

Educational technology has served to change adult education from a teacher-centred approach to a learner-centred. approach. This means that all possible resources (whether people, media, things, places etc.) are made available to the learner. The learner is put into the position of taking more responsibility for his learning and to participate more actively in the learning situation. This is supported by a system of guidance and is structured to help the student develop specified competencies.

It is predicted that by the year $200010-20 \%$ of on-campus students will be involved in learning situations based on all aspects of educational technology and $80 \%$ of students off campus. (Carnegie Commission on Higher Education. June 1972)

Through an effective use of educational technology the teacher can multiply herself many times over as far as oneway communication of information is concerned. This frees her from the repetitive task of teaching in order to build more meaningful two-way communication and interaction with the student. She is able to ensure that learning experiences and instructional materials assist the student to reach pre-stated educational objectives, to effect a goaldirected change in behaviour and action, or to achieve a satisfactory learning outcome in terms of knowledge, skills and attitudes. 
All this is very relevant to nursing education because modern nursing is expanding rapidly in terms of knowledge, skills and attitudes. Furthermore, it is expanding in terms of intellectual requirements. Because of this the teacher needs to make use of the newest classification of intellectual abilities as related to required educational outcomes. These are to be found in Bloom's Taxonomy of Educational Objectives of which there are two handbooks, one dealing with the cognitive domain and the other with the affective domain.

The stated intellectual abilities and their related learning outcomes (or objectives) as set out by Bloom can be interpreted as a type of learning pyramid as set out below:

\section{PYRAMID OF ABILITIES IN RESPECT OF THE COGNITIVE DOMAIN}

(Summarised from Bloom et al)

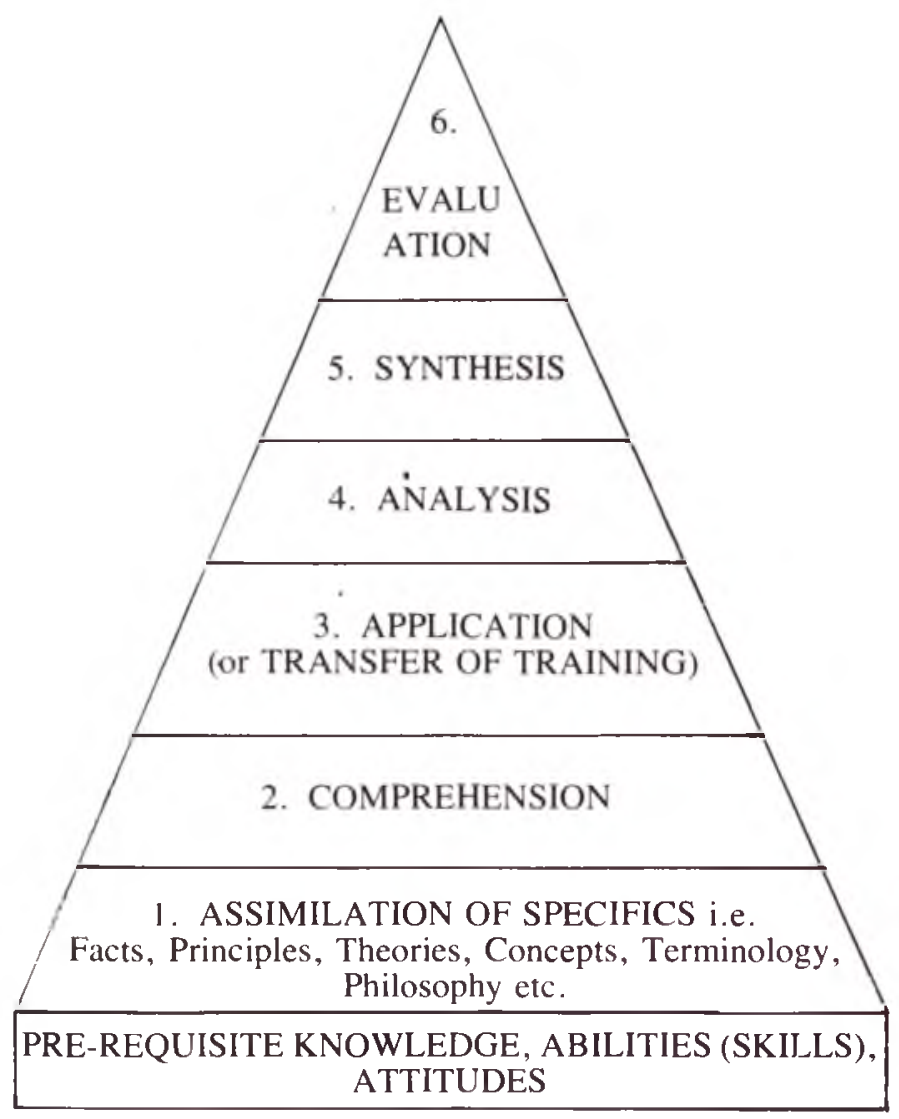

Where

1. ASSIMILATION OF SPECIFICS is evidenced by the ability to recall or recognise the same.

2 - 6 i.e. Comprehension. Application. Analysis, Synthesis and Evaluation are evidenced by the ability to relate things, facts etc. to situations, or problems. Apply laws, principles etc. in the actual situation, observe significant changes, and indicate or act upon differences between variations; discriminate between global and detailed, make judgements between correct, incorrect etc. make decisions as a result of drawing conclusions, etc.

\section{PYRAMID OF ABILITIES IN RESPECT OF THE AFFECTIVE DOMAIN}

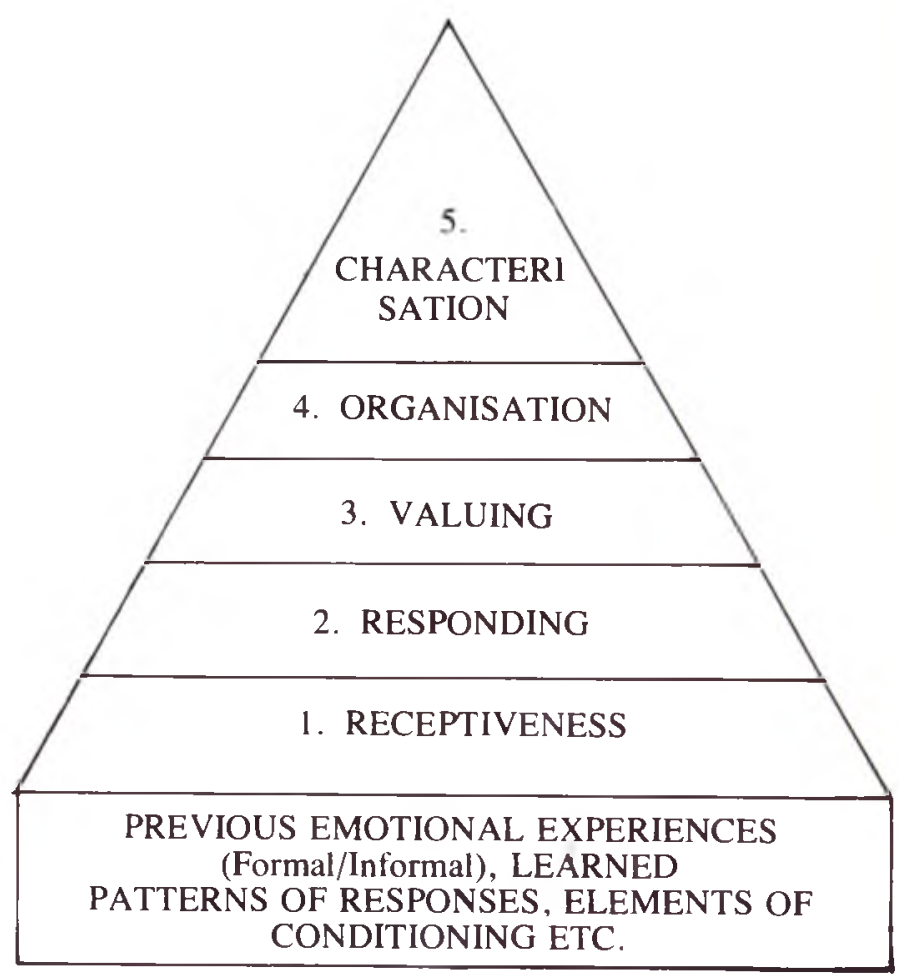


If the learning outcomes and their relationship to the levels of intellectual abilities and affective states as expressed by Bloom in his book - are carefully considered we can well ask ourselves as nurse-educators how far up the scale do we permit and encourage student nurses to go when on basic courses?

Yet, in fact, as soon as they become practising registered nurses they are required to function at very high levels if they are to be competent. They become involved in situations which require a highly complex range of abilities not only in the psycho-motor domain but also in the cognitive and affective domains.

What leaming experiences are purposefully structured into the implementation of the basic curricula to help the students to develop some of the higher intellectual abilities such as analysis, synthesis and evaluation? Or do too many of our programmes, basic and postbasic, revolve around only the foundation abilities of recall, recognition and assimilation, i.e. assimilation of specifics.

The application of a systematic approach to the learning situation can include application of Bloom's Taxonomy by choosing suitable learning experiences.

A systematic approach to curriculum design involves knowledge of the student in the total context as well as the individual learning needs. Time is taken to assess and obtain pre-requisite learning and ability before being allowed on course. A pre-test is done to assess the student's present knowledge of the course content, and thereafter the student proceeds to do only that part of the course in which he is not already proficient, thus saving effective learning time. Progress tests and a post-test will indicate rate and level of achievement.

Learning is evaluated against pre-stated objectives and the student therefore not only knows beforehand the expected learning outcomes, but can see how far they have been attained in experience. This leads to improved learning satisfaction.

According to the type of learning to be done, special learning experiences and resources are selected and provided for the student to enable the learning competencies to be achieved as soon as possible. This prevents demotivation. Key information and guidance are provided by the teacher in different ways, while interaction between teacher and student is built in at individual and small group sessions.

In this type of learning situation the concept of the "total" teacher should be applied and developed i.e. individual differences between students are recognised and catered for. Flexibility in teachers becomes a necessity as also the ability to manage the total learning situation in such a way as to enable the student to reach the pre-determined objectives. The teacher does not rely on being a "driver" or "motivator" of students, but becomes totally involved with each student so as to be able to assess, encourage and develop her throughout the period of learning. The teacher gets to know the student's reactions, attitudes, and learning abilities or problems early enough to act remedially, or to use them to further the student's progress.

The methods chosen should provide for individual differences in students in that they should vary from self-learning through to large-group instruction. They should be chosen to stimulate individual or group participation where they will assist the student in the attainment of the stated learning objectives.

The learning environment, both psychologically and physically, should be such as to support the student.

The "total" teacher is one who is not "task orientated" but is "person situation" orientated: Also teaching should be viewed as a professional occupation holding the concepts of the rights of the client and the professional's responsibilities to the client. Therefore the possibility of malpractice is a reality. This can be said to occur when the student either fails to meet the required learning needs in a given situation, or is demotivated, or fails to develop to full potential. Therefore the "total" teacher embraces any aspects of the modern sciences which will help to make the teaching situation more effective.

Today the required sciences include those of management, communication, and educational technology.

The total teacher sees teaching as an art involving the personality of the teacher and the building of a trustful student-teacher relationship, based on personal confidence and the ability to lead. guide and direct at crucial moments in the learning situation.

Teaching is seen as a personal challenge to build up the capacities of the student in such a way that they are able to function effectively in the future professional role. This means that the required competencies must be analysed and clearly stated prior to designing a curriculum.

Teaching is also seen as the transmission of knowledge, skills, attitudes and values to the one who is becoming professional. Teaching therefore must be based on dynamic communication and the learning situation must be student-centred and not teachercentred.

Teacher-centred methods are those which put the emphasis on teacher presentation, while learnercentred methods make use of techniques which will involve the student in active participation in the learning situation. This participation should be structured in such a way as to help students become aware of and identify their own strengths and weaknesses, their roles and responsibilities within the group, and to acquire skills in information. retrieval and communication. Partnership methods involve techniques which provide for close mental interaction between the teacher and student viz. question and answer, tutorials, counselling, discussion projects requiring report-back in some active form. 
Really good teacher presentation and exposition can be an excellent means of inspiring, motivating, stimulating and informing. It has a valuable place if not hopelessly overdone.

A "total" teacher accepts the concept of team teaching, and is willing to be part of a team and make her contribution within that framework.

Also such a teacher can identify when there is a shift in emphasis from training to education and vice versa. and can attempt to move as far as possible in the direction of education.

Training involves imitative reaction, short-range limited goals and fixed ceilings, fixed inflexible methods, memorisation and repetition. unexamined conformity, a limited sharing of ideas and feelings, and learning by prescription - all of which tend to produce a dependent learner who is liable to become fixed in a dependent state.

This type of class teaching is often traumatic to teachers, especially student teachers and new teachers. In a training type situation TEACHING IS VIEWED AS A PERFORMANCE by the teacher while the forced passivity of the students can tend to demotivate the active type of leamer.

Education on the other hand, provides for creative, imaginative or reflective mental processes, the inclusion of long-range broad goals and flexible ceilings; and variable means of achieving learning outcomes, thoughtful practice and application, thoughtful conformity and non-conformity, unlimited sharing of ideas and feelings, learning by thinking - and the production of an independent learner who has learned how to learn.

Training has its place in nursing, but an over emphasis in this direction does not provide for the development of intellectual abilities or desired attitudinal changes.

A "total" teacher looks at both teacher-based and resource-based systems of learning and selects what will be best for the student and the learning situation.

Teacher-based systems can require much passive listening caused by excessive teacher-talk, and may be based on uniformity of lesson-content as well as uniformity of pace and style. They may fail to deal effectively with mixed ability classes and usually demand a rigid timetable with the emphasis on subject specialists. They usually revolve around consecutive short bursts of teaching with little or no opportunity for reflective work or extended periods of discovery or problem-solving.

Resource-based learning however includes a selection of active forms of learning. It allows for different students to have different learning experiences at the same time. It can be adapted much more to individual differences. It works successfully with mixed ability classes and allows for greater flexibility.
Resource-based learning requires the provision of all those learning resources which will provide for improved learning, and can be defined as "anything in the environment that may be of value in forwarding the thinking and understanding of the students whether it be an artefact, a person or expert, an account. an explanation, a piece of information, an audio-or visual or audiovisual communication." (Holder \& Wilson 1974). Resources are part of the designed learning experience and must be managed by the teacher. the student or the librarian, or a combination of these persons. In nursing the provision of resources is done best by means of hospitalbased as well as college-based resource centres which make all required learning resources accessible to students.

The choice of media, resources and learning experiences to be implemented in the curriculum should take into account the Cone of Learning Experience (Dale, Edgar; Audiovisual Methods in Teaching, 3rd Edition 1969, Dryden Press, New York). This enables the teacher to be more purposeful and specific and choose according to the complexity of the work to be learned as well as the intellectual abilities to be developed.

The management of a resource centre in an institution should be based on the following principles, features, and conditions: (Council for Educational Technology, working Paper 10; Resource Centres in Colleges of Education)

\section{Principles}

1. The availability of resources to all students and teachers.

2. The possibility of full utilisation of resources at periods when required by students.

3. Provision for mixed ability students at various levels of training.

4. Provision for flexibility and integration of resources and media.

5. Promotion and provision for individual self-instruction under a system of available guidance.

\section{Features}

1. A resource centre should fultil all the functions of a conventional-type library.

2. Material and equipment should be ready for immediate use at all times.

3. There should be adequate accommodation for storage of reference sources, for preparation of material, and for student-learning space whether as individuals or groups

4. There should be provision for a wide range of playback equipment i.e. for viewing or listening; and also of materials for production. 


\section{Conditions}

1. The resources system must be suitable eg. interlocking of services between classroom. institution and region all organised as one integrated resources service.

Fast and efficient retrieval must be part of the system, and co-ordination of services is desirable.

2. The control system must be effective and not hinder the service.

3. The learning system must be adaptive to each unit of work and should utilise the principles of educational technology.

4. New roles and new skills must be developed by the teacher.

RESOURCE-BASED LEARNING WILL NOT SUCCEED UNLESS TEACHERS ARE WILLING AND ABLE TO DEVELOP THESE SKILLS

5. Teachers must participate in the design of learning resources.

Also a learning resources system for teachers and learners should provide a support service in that four main functions of the resource centre should be included viz. a provision function, a production function, an instructional function, and a consultative function. These four functions should flow throughout the system from the central resources centre through the institution resources centre to the point of delivery within the student environment.

\section{APPLICATIONS TO NURSING EDUCATION}

Having said all this, how can the principles of educational technology and resource-based learning be applied to basic courses in nursing education?

One approach is an instructional modules system of ward-based self-instruction to form the basis of continuous study between College Blocks.

This approach is designed to give nurses all the possible learning experiences related to their ward-placement and to make available to them such learning resources as are possible at this stage.

One current experiment consists of the following:

The establishment of a hospital-based Department of Nursing Education having four arms:

(a) Selection and Appointments.

(b) Individualised Learning Skills.

(c) Clinical Instruction.

(d) Evaluation

The department to fall under a Principal Matron and to be developed to include all basic and post-basic education.

The arm of individualised learning skills is the first to be developed. An instructional design team made up of tutors, clinical instructors, matrons and ward sisters is writing a series of self-learning modules based on competencies to be learnt in a given clinical situation.

The pattern on which the modules are built consists of a series of Orientation, Basic, Advanced, Specialised and Developmental modules respectively. In order to write a module the competencies to be developed in the ward-based situation are first assessed, listed and then stated in the form of learning objectives. A short introduction to the module leads into the learning objectives. A list of related reading material, audiovisual aids, and relevant visits to persons or departments within the hospital is included. Then learning experiences and exercises to be carried out in the ward situation are designed - one or more to fit each stated learning objective.

A system of placement of a variety of modules in the wards is used, and required resources are made available both in the wards and in the resource centres in hospital and college.

Nurses may choose which modules they wish to do, but they are guided in their choice according to level of ability, experience and type of ward. Nurses commence doing the orientation modules such as "The Nursing Process" "Observing your Patient", "Meeting the Psychological and Spiritual Needs of the Patient", "Meeting the Physical Needs of the Patient", etc. during their first months of training and prior to the first college block.

Support to the nurses is given by the sisters in the wards, tutors (both hospital-based and on rotation from the College), and clinical instructors. They assist the nurse in the choice of module, in understanding how to commence it, and on a continuous basis as she proceeds.

Evaluation based on the stated ward competencies to be learnt is done by the nurse herself, the ward sister on a day-to-day basis, and the tutor-supervisor at the end of the project. The nurse's development is closely watched and carefully recorded and can be a basis for reference when she goes to College.

So far the experimental project which began in January is going smoothly and the response from the nurses has been positive and encouraging.

The project is based on Tygerberg Hospital, under the control of Miss M. Hartman. and Sister Tutors from Otto du Plessis Nursing College and Sarleh Dollie Nursing College are participating on a rotation basis. One tutor is hospitalbased and two senior matrons who are tutor-trained, are helping to guide the project.

In the writing of the modules cognisance is taken of Bloom's Taxonomy although this can be developed to a more sophisticated level in the Developmental Modules when these are written.

Audiovisual material is gradually being designed or produced and this will be augmented once the writing of the modules is completed.

By the end of 1978 an assessment can be made as to progress. Final assessment will be made when the January appointments complete their training

Many applications of educational technology are feasible in nursing education, as also in medical education and will help to provide the nurse with a continuous system of learning, rather than only the "Block" System learning. This should help to provide a good foundation for the development of professional competencies and continuing education.

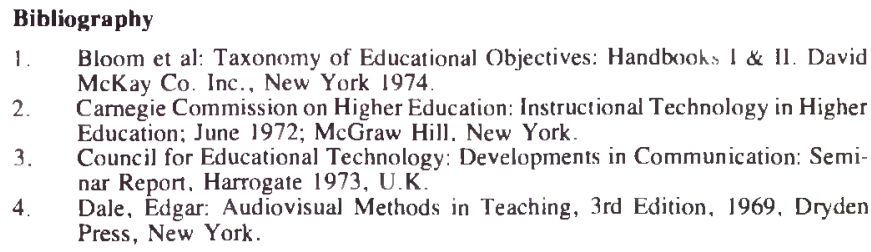

